\title{
STUDIES ON LAPAROSCOPIC INTRAUTERINE INSEMINATION OF BARKI EWES (USING DIFFERENT INSEMINATION DOSES) AS COMPARED WITH CERVICAL INSEMINATION
}

\author{
EL-BADRY, D.A.; ; AML Z. LEIL ${ }^{* *}$ and MONA H. SHAKER * \\ *Artificial Insemination and Embryo Transfer Dept. Animal Reproduction Research Institute, Agriculture Research Center, \\ Giza, Egypt \\ ${ }^{* *}$ Dept. of Field Investigations, Animal Reproduction Research Institute, Agriculture Research Center, Giza, Egypt
}

Email: diyabadry@hotmail.com

\section{ABSTRACT}

Received at: $1 / 6 / 2014$

The present study aimed to investigate the efficacy of laparoscopic intrauterine insemination as compared with cervical insemination in Barki ewes as well as to set

Accepted: 10/9/2014 the optimum number of spermatozoa per laparoscopic insemination. A total of 33 oestrus-synchronized Barki ewes were divided into four groups, the first three groups were inseminated laparoscopically with either $10 \times 10^{7}$ (group 1), $20 \times 10^{7}$ (group 2) or $40 \times 10^{7}$ sperm/dose (group 3). The $4^{\text {th }}$ group was cervically inseminated. The results showed that lambing rate after laparoscopic intrauterine insemination using $20 \times 10^{7}$ spermatozoa $(75.00 \%)$ was superior to either laparoscopic insemination using 10 or $40 \times 10^{7}$ spermatozoa or cervical insemination using $80 \times 10^{7}$ spermatozoa $(37.50 \%, 62.50$ and $55.56 \%$, respectively). Conclusively, intrauterine insemination using the technique of laparoscopy is a relatively simple, field applicable and convenient mean of achieving high lambing rates. Furthermore, $20 \times 10^{7}$ motile spermatozoa is the recommended laparoscopic insemination dose in Barki ewes.

Key words: Laparoscopic, Intrauterine insemination, Barki ewes.

\section{INTRODUCTION}

Artificial insemination has become an important adjunct for breeding certain domestic species because of its great advantage for exploiting the genetic potential of superior sires. It has been known for quite long time that cervical insemination in sheep though commercially widely used, does not render satisfactory fertilization rate (Amiridis and Cseh, 2012). The cervical canal of the ewe has a convoluted and tortuous structure, reflecting the presence of 5-7 annular folds or cervical rings (Kershaw et al., 2005; Kaabi et al., 2006) that prevent trans-cervical intrauterine insemination (Kaabi et al., 2006).

Laparoscopic approach for intrauterine semen deposition is an easy technique, however, giving acceptable fertilization rates in estrous synchronized ewes (Lymberopoulos et al., 2001; Naqvi et al., 2001;
Evans et al., 2002; Hiwasa et al., 2009). The advantage of laparoscopic insemination is that the semen is deposited closer to the site of fertilization. Deep uterine insemination has been shown to be advantageous in several domestic species, such as sheep (Salamon and Maxwell, 1995; WulsterRadcliffe et al., 2004), goats (Ritar and Salamon, 1983; Moore et al., 1988), cattle (Lopez-Gatius, 2000; Verberckmoes et al., 2004), horses (Morris and Allen, 2002), and pigs (Martinez et al., 2002; Rath, 2002; Watson and Behan, 2003), especially when sperm numbers are limited or sperm quality is suboptimal.

The site of insemination of ram semen has a major effect on pregnancy rate in sheep, with greater rates achieved following laparoscopic AI than following either transcervical (Wulster-Radcliffe et al., 2004) or cervical insemination (Fair et al., 2005). Using laparoscopy, the "cervical barrier" problem has been overcome and satisfactory fertility rate has been 
achieved by significant reduction in the number of spermatozoa per insemination (from 200-300 to 1-10 millions, or less for sex-sorted semen, Salamon and Maxwell, 2000).

The major objectives of this study were; to compare the pregnancy and lambing rates of ewes inseminated either cervically or by intrauterine laparoscopic insemination and to determine the minimal sperm dose per intrauterine insemination in order to maximize the genetic diffusion of males, without decreasing AI success.

\section{MATERIALS and METHODS}

\section{Animals and treatment:}

Thirty six mature, clinically healthy Barki sheep (3 rams and 33 ewes), aged 2.0 -2.5 years were assigned to the study. Animals were kept in the experimental farm of the Animal Reproduction Research Institute (ARRI), and they were divided into four groups, the first three groups ( 8 ewes in each) were inseminated laparoscopically with either $10 \times 10^{7}$ (group 1), $20 \mathrm{x}$ $10^{7}$ (group 2) or $40 \times 10^{7}$ sperm/dose (group 3). The last group (group 4 containing 9 ewes) was transcervically inseminated with $80 \times 10^{7}$ sperm/dose (Gordon, 1997).

\section{Collection of semen:}

Semen was collected from trained rams with an artificial vagina that was adjusted to a proper condition, diluted at $30^{\circ} \mathrm{C}$ with Tris-based diluent to provide a sperm concentration of $80 \times 10^{7} / \mathrm{ml}$, cooled slowly and kept at $16^{\circ} \mathrm{C}$ for up to $6 \mathrm{~h}$ (Langford et al., 1979). Only rams with at least $70 \%$ motile spermatozoa and good progressive motility were used. Just before insemination, dilutions were made at $16^{\circ} \mathrm{C}$ using Tris-based diluent to provide concentrations of $80,40,20$ and $10 \times 10^{7} / \mathrm{ml}$.

\section{Synchronization of estrus:}

The estrous cycles were synchronized using CIDR's (EAZI-BREED, CIDR $\AA$, New Zealand), inserted for a period of 14 days (Sirjani et al., 2012). eCG (250 IU; Folligon; Germany) intramuscularly injected to ewes at the time of CIDR removal. The laparoscopic and cervical inseminations were performed on the $58^{\text {th }}$ hour after removal of CIDR (Bonev et al., 2005).

\section{Laparoscopic artificial insemination:}

Laparoscopic procedures were done using Wolf Laparoscope (Wolf Co., Germany) of $5 \mathrm{~mm}$ diameter, $33 \mathrm{~cm}$ length and $0^{\circ}$ scope viewing angle. Automatic insufflator was used to deliver the $\mathrm{CO}_{2}$ intraperitoneally (pressure $10 \mathrm{mmHg}$ ). Laparoscopic insemination, in details was described by Toni et al. (2012). Briefly, ewes were fasted and restricted access to water at least for 16 hours before laparoscopy, and injected intravenously with xylazine hydrochloride (Xylaject 2\%, Adwia) at a dose rate of $0.05 \mathrm{mg} / \mathrm{kg}$ b.w. Local anesthetic (Lidocaine $2 \%$ ) was injected 10 minutes before the procedure was performed. The ewe was then placed in a laparoscopy cradle. The abdominal region was surgically prepared by shearing the wool and disinfecting the skin. Using the cradle, the ewe was positioned in a supine headdown (Trendelenburg) position to an approximate angle of $30^{\circ}$ (Fig 1). A scalpel blade was used to make a small skin incision in order to facilitate trocar penetration (Fig 2). The trocars and cannulae for introducing laparoscope and insemination pipette were inserted 7-10 cm ventral to the udder and 5-10 $\mathrm{cm}$ on each side of the midline (linea alba). The 5$\mathrm{mm}$ Verus needle that was connected with the $\mathrm{CO}_{2}$ is first introduced and the abdomen was slightly inflated to reduce the chance of injury to organs. Insertions of the first trocar and cannula should be well controlled and the sharp trocar was withdrawn as soon as the abdominal wall has been penetrated. The blunt cannula was pushed well into the abdomen, while the second trocar and cannula were inserted after inflation with $\mathrm{CO}_{2}$. Endoscope and $\mathrm{AI}$ instrument went through the cannulae (Fig 3) and the uterus was located and fixed using the grasping forceps just ventral to the urinary bladder. Semen was deposited in the lumen of each uterine horn approximately halfway between the uterine bifurcation and the utero-tubal junction (Fig. 4). Instruments were withdrawn and putted into disinfectants between each animal. An antibiotic spray was applied to the wounds before it was sutured. The sutures were removed 7 days later. 


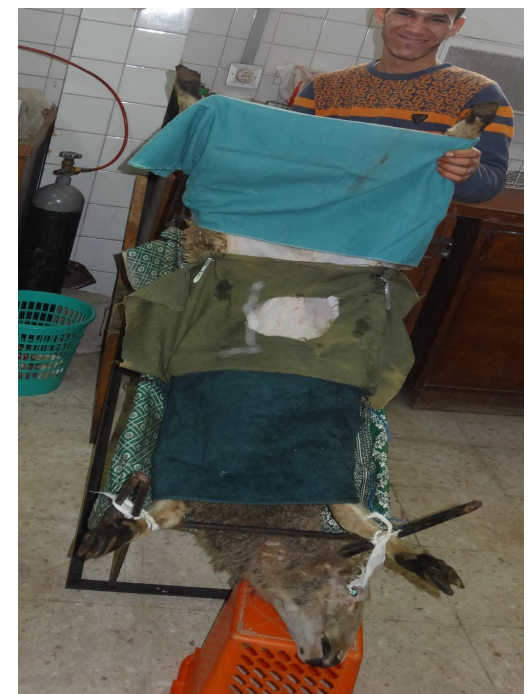

Fig. 1: Positioning of the animal in a supine headdown position for laparoscopy

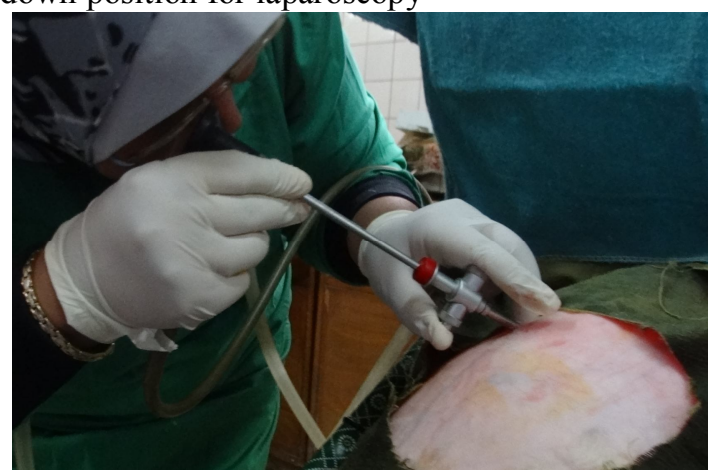

Fig. 3: Endoscope went through the cannulae for visualization of uterus

\section{Cervical artificial insemination:}

The cervix was located, via a speculum fitted with a light source. The cervix of the ewe is convoluted in structure and does not dilate during oestrus. As a result it was generally only possible to deposit the semen $\left(80 \times 10^{7}\right.$ sperm $)$ in the first fold of the cervix.

\section{Pregnancy diagnosis:}

Pregnancy rate (pregnant ewes/treated ewes ratio) was determined 35 days after AI by trans-abdominal ultrasonography examination using an Exagyne ECM, France) machine provided with a $6.5 \mathrm{MHz}$ linear probe. Pregnancy loss in ewes was calculated as the number of ewes pregnant at Day 35 - the number of lambed ewes / number of ewes pregnant at Day 35.

\section{Statistical analysis:}

The recorded data among all treatment groups was analyzed by Chi square analysis. The level of significance was observed at 5\% (Snedecor and Cochran, 1989).

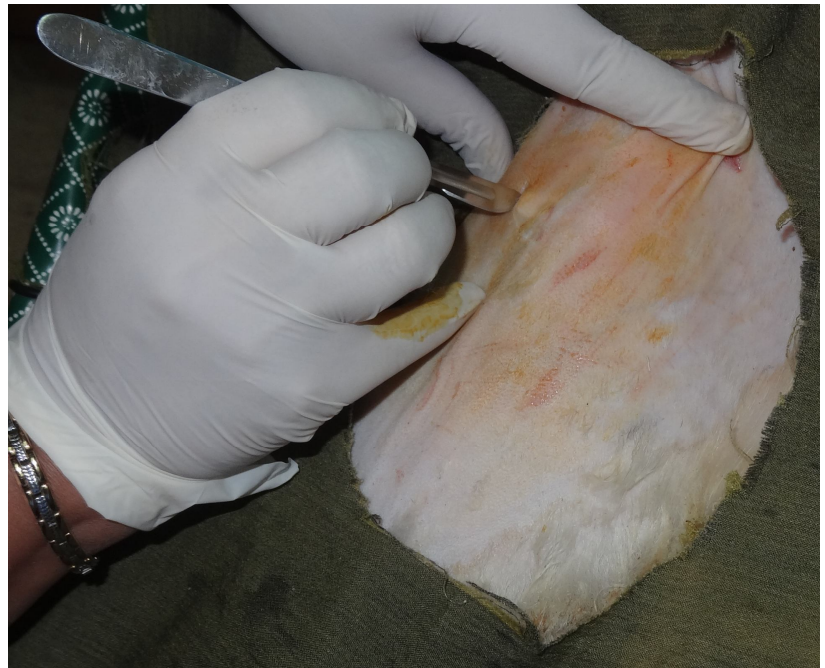

Fig. 2: A small skin incision in order to facilitate trocar penetration

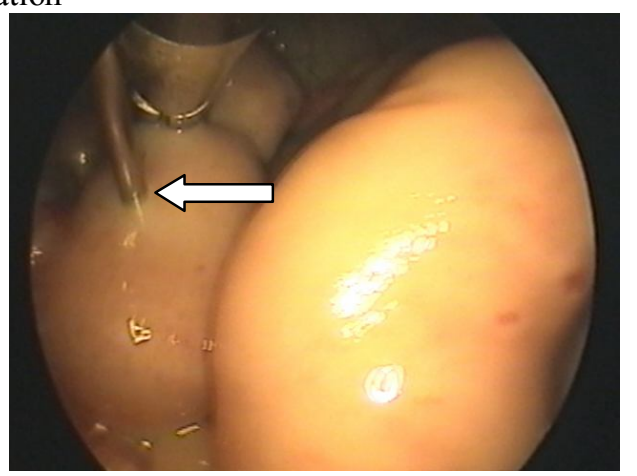

Fig. 4: The recommended site of puncture for semen deposition is the major curvature of the uterine horn (arrow).

\section{RESULTS}

Regarding the results of laparoscopic intrauterine insemination (table 1), the insemination dose of $20 \mathrm{x}$ $10^{7}$ spermatozoa (group 2) and $40 \times 10^{7}$ spermatozoa (group 3) resulted in the same pregnancy rate at 35 days post-insemination $(75.00 \%$ for each). However, insemination of $20 \times 10^{7}$ spermatozoa resulted in significantly $(\mathrm{P} \leq 0.05)$ higher lambing rate when compared with using $10 \times 10^{7}$ and $40 \times 10^{7}$ spermatozoa $(75.00 \%$ vs. 37.50 and $62.50 \%$, respectively). On the other hand, ewes of group 1 had the significantly higher rate of pregnancy loss $(40.00 \%)$ when compared with rates of groups 2 and $3(0.00 \%$ and $16.67 \%$, respectively).

The results presented in table (1) revealed that, laparoscopic intrauterine insemination using optimum insemination dose $\left(20 \times 10^{7}\right.$ spermatozoa, group 2$)$ was superior to cervical insemination using $80 \times 10^{7}$ spermatozoa (group 4) in terms of pregnancy rate $(75.00 \%$ vs. $55.56 \%$, respectively) and lambing rate (75.00\% vs. $55.56 \%$, respectively). 
Table 1: Pregnancy and lambing rates of ewes after cervical and laparoscopic intrauterine insemination using different insemination doses.

\begin{tabular}{lcccc}
\hline $\begin{array}{c}\text { Method of } \\
\text { Insemination }\end{array}$ & \multicolumn{2}{c}{ Laparoscopic intrauterine Insemination } & $\begin{array}{c}\text { Cervical } \\
\text { Insemination }\end{array}$ \\
\hline Treatment Groups & GP1 & GP2 & GP3 & GP4 \\
\hline Insemination dose (sperm) & $10 \times 10^{7}$ & $20 \times 10^{7}$ & $40 \times 10^{7}$ & $80 \times 10^{7}$ \\
\hline No. of ewes inseminated & 8 & 8 & 8 & 9 \\
\hline No. of pregnant ewes (\%) & $5(62.50)^{\mathrm{b}}$ & $6(75.00)^{\mathrm{a}}$ & $6(75.00)^{\mathrm{a}}$ & $5(55.56)^{\mathrm{c}}$ \\
\hline Lambing rate $(\%)^{\mathrm{a}}$ & $3(37.50)^{\mathrm{d}}$ & $6(75.00)^{\mathrm{a}}$ & $5(62.50)^{\mathrm{b}}$ & $5(55.56)^{\mathrm{c}}$ \\
\hline Pregnancy loss $(\%)$ & $2(40.00)^{\mathrm{a}}$ & $0(0.00)^{\mathrm{c}}$ & $1(16.67)^{\mathrm{b}}$ & $0(0.00)^{\mathrm{c}}$ \\
\hline
\end{tabular}

Values with different superscripts in the same raw differs significantly at least at $\mathrm{P}<0.05$

\section{DISCUSSION}

In the current study, the lambing rate after laparoscopic insemination using $20 \quad \times \quad 10^{7}$ spermatozoa (group 2) was significantly $(\mathrm{P} \leq 0.05)$ higher than that after cervical insemination using $80 \mathrm{x}$ $10^{7}$ spermatozoa ( $75.00 \%$ vs. $55.56 \%$, respectively). Similarly, Rojero et al. (2009) concluded that middle fertility rate of $43.7 \%$ resulting from cervical insemination in ewes can be considered as acceptable, but it is no possible to obtain similar fertility rate $(75.00 \%)$ as with laparoscopic intrauterine insemination. Artificial insemination techniques have been considered in many previous studies. According to several authors (Armstrong and Evans, 1984; Rodriguez et al., 1988; Correa et al., 1994; Byrne et al., 2000; Romano, 2013), laparoscopic insemination ensures significantly higher parturition rates than trans-cervical insemination, despite the fact that relatively lower numbers of spermatozoa are used. This difference in fertility can be explained by the fact that the sheep cervix has a very high structural complexity, preventing deep cervical insemination (Halbert et al., 1990; Kaabi, 2002). Laparoscopic insemination allows this barrier to be bypassed, improving fertility even with lower quality spermatozoa (Salamon and Maxwell, 2000; Naqvi et al., 2001).

The lambing rate of $75.00 \%$ achieved after laparoscopic intrauterine insemination in present study coincided with the same rates $(75.00 \%)$ reported by McKelvey et al. (1985) and Rojero et al. (2009), and higher than lambing rates of $48.00 \%$, $71.10 \%, 43.90 \%, 72.70 \%, 60.00 \%, 71.00 \%$ and $71.40 \%$ reported by Windsor et al. (1994), Hill et al. (1998), McKusick et al. (2000); Paulenz et al. (2005), Toni et al., 2012, Al-Wataar (2009) and Alfaris et al. (2012), respectively. Sayre and Lewis (1997) reported a higher lambing rate $(92.50 \%)$ after intrauterine insemination. Concerning the cervical insemination, the lambing rate of $55.56 \%$ achieved after cervical insemination in this study was similar to that (57.00\%) reported by Ghalsasi and Nimbkar (1996), and lower than lambing rates of $68.60 \%, 78.00 \%$, $69.00 \%, 67.00 \%, 65.75 \%$ and $60.00 \%$ reported by Lightfoot and Salamon (1970), Langford et al. (1979), Tervit et al. (1984), McKelvey et al. (1985), Donovan et al. (2000), Nour et al. (2010), respectively, and higher than lambing rates of $43.70 \%$ and $50.00 \%$ reported by Rojero et al. (2009) and AlWataar (2009), respectively. The fertility rates following cervical and laparoscopic insemination all vary with the insemination technique used as well as with the farm, age, male, number of insemination per ewe, lambing-insemination interval, technician, flock and management conditions (Anel et al., 2005; Paulenz et al., 2005).

In sheep, the numbers of spermatozoa used by intrauterine insemination were reported to be 80 million (Windsor et al., 1994), 150 million (Halbert et al., 1990; Buckrell et al., 1994), 200 million, (Lawrence, 1985; Husein et al., 1998a) and 400 million (Smith et al., 1995; Husein et al., 1998b). In general, the numbers of spermatozoa used for intrauterine insemination are higher than the recommended numbers used for trans-cervical artificial insemination (Maxwell and Hewitt, 1986; Ritar, 1993; Romano, 2013). In the current study, a low intrauterine insemination dose $\left(10 \times 10^{7}\right)$ resulted in decreased lambing rate $(37.50 \%)$, whereas a higher insemination dose $\left(20 \times 10^{7}\right)$ increased lambing rate $(75.00 \%)$ and this result was in agreement with other researches (Maxwell and Salamon, 1993; Martin and Watson, 1976; Emsen et al., 2011). Higher dose of spermatozoa $\left(40 \times 10^{7}\right)$ was not recorded with significant increase in lambing rate $(62.50 \%)$. This 
result came in accordance with the findings of Emsen et al. (2011). Thus, it can be recommended that the minimum necessary for laparoscopic artificial insemination in Barki ewes is $20 \times 10^{7}$ motile spermatozoa. Similarly, Milczewski et al. (2000) recommended that higher pregnancy rates $(69.56 \%)$ could be obtained with at least $25 \times 10^{7}$ spermatozoa per dose in intrauterine inseminations of ewes. On the other hand, Leethongdee (2010) recommended a minimum number of $40 \times 10^{6}$ spermatozoa per laparoscopic insemination. Also, Evans and Maxwell (1987) recommend a minimum dose of only $20 \times 10^{6}$ motile sperm while there are several reports of acceptable fertility $(>50 \%)$ using doses as low as $5 \mathrm{x}$ $10^{6}$ (Eppleston et al., 1986) and $10 \times 10^{6}$ (Salamon et al., 1985) motile spermatozoa. Furthermore, acceptable levels of fertility were achieved after lowdose insemination using flow cytometrically sorted ram sperm at a dose of $1 \times 10^{6}$ motile sperm per ewe (de Graaf et al., 2007).

In conclusion, as compared to cervical insemination, intrauterine insemination using the technique of laparoscopy is a relatively simple and convenient mean of achieving high lambing rates in Barki ewes. The recommended insemination dose for laparoscopic artificial insemination of Barki ewes was $20 \times 10^{7}$ motile spermatozoa.

\section{REFERENCES}

Alfaris, A.A.; Fahid, T.A.; Jafer, B. and Al-Dahabi, H. (2012): Laparoscopic intrauterine artificial insemination and ultrasonic pregnancy diagnosis in Arabi ewes. J. Evolutionary Biol. Res., 4: 1-12.

Al-wataar, B.D.; Taha, M.B. and Al-Badrany, M.S. (2009): Co-operation of Laparoscopic intrauterine insemination in synchronized Awassi ewes. J. Iraqi Vet. Sci., 22: 53 - 57.

Amiridis, G.S. and Cseh, S. (2012): Assisted reproductive technologies in the reproductive management of small ruminants. Anim. Reprod. Sci., 130: 152-161.

Anel, L.; Kaabi, M.; Abroug, B.; Alvarez, M.; Anel, E.; Boixo, J.C.; de la Fuente, L.F. and de Paz, $P$. (2005): Factors influencing the success of vaginal and laparoscopic artificial insemination in churra ewes: a field assay. Theriogenology, 63: 1235-1247.

Armstrong, D.T. and Evans, G. (1984): Intrauterine insemination enhances fertility of frozen semen in superovulated ewes. J. Reprod. Fertil., 71: 89-94.

Bonev, G.B.; Vassilev, N.Y.; Dimitrov, M.A.; Yotov, S.A. and Penchev, P. (2005): Adjustment of echography and laparoscopic insemination to the reproductive particularities of pleven blackhead sheep. Bulgarian J. Vet. Med., 9: 61-65.
Buckrell, B.C.; Buschbeck, C. and Gartley, C.J. (1994): Further development of a transcervical technique for artificial insemination in sheep using previously frozen semen. Theriogenology, 42: 601-611.

Byrne, G.P.; Lonergan, P.; Wade, M.; Duffy, P.; Donovan, A. and Hanrahan, J.P. (2000): Effect of freezing rate of ram spermatozoa on subsequent fertility in vivo and in vitro. Anim. Reprod. Sci., 62: 265-275.

Correa, J.E.; Bergmann, B. and Gatica, R. (1994): Fertilization rate in sheep unilaterally inseminated with frozen semen. Small Rumin. Res., 13: 99-101.

de Graaf, S.P.; Beilby, K.; O’Brien, J.K.; Osborn, D.; Downing, J.A.; Maxwell, W.M. and Evans, G. (2007): Embryo production from superovulated sheep inseminated with sexsorted ram spermatozoa. Theriogenology, 67: 550-555.

Donovan, A.; Hanrahan, D.A.; Duffy, P. and Boland, M.P. (2000): AI in sheep: breed differences in timing of ovulation. Proc. $26^{\text {th }}$ Agric. Res. Forum, Dublin.

Emsen, E.; Gimenez-Diaz, C.; Kutluca, M. and Koycegiz, F. (2011): Reproductive response of ewes synchronized with different lengths of MGA treatments in intrauterine insemination program. Anim. Reprod. Sci., 126: 57-60.

Eppleston, J.; Maxwell, W.M.C.; Battye, K.M. and Roberts, E.M. (1986): Effect of thawed motility and intrauterine dose of motile sperm on fertility of ewes. Proc. Aust. Sot. Reprod. Biol., 18: 19 abstr.

Evans, A.C.; Flynn, J.D.; Duffy, P.; Knight, P.G. and Boland, M.P. (2002): Effects of ovarian follicle ablation on $\mathrm{FSH}$, oestradiol and inhibin A concentrations and growth of other follicles in sheep. Reprod., 123: 59-66.

Evans, G. and Maxwell, W.M.C. (1987): Salamon's Artificial Insemination in Sheep and Goats. Sydney: Butterworths.

Fair, S.; Hanrahan, J.P.; O'Meara, C.M.; Duffy, P.; Rizos, D.; Wade, M.: Donovan, A.; Boland, M.P. and Lonergan, P. (2005): Evans Differences between Belclare and Suffolk ewes in fertilization rate, embryo quality and accessory sperm number after cervical or laparoscopic artificial insemination. Theriogenology, 63: 1995-2005.

Ghalsasi, P.M. and Nimbkar, T. (1996): Evaluation of laparoscopic intrauterine insemination in ewes Small Rum. Res., 23: 69-73.

Gordon, I. (1997): Controlled Reproduction in Sheep and Goats. Cab International (U.S.A.).

Halbert, G.W.; Dobson, H. and Walton, J.S. (1990): The structure of the cervical canal of the ewe. Theriogenology, 33: 977-992.

Hill, J.R.; Thompson, J.A. and Perkins, N.R. (1998): Factors affecting pregnancy rates following 
laparoscopic insemination of 28,447 Merino ewes under commercial conditions: a survey. Theriogenology, 49: 697-709.

Hiwasa, M.; Kohno, H.; Togari, T.; Okabe, K. and Fukui, Y. (2009): Fertility after different artificial insemination methods using a synthetic semen extender in sheep. J. Reprod. Dev., 55: 50-54.

Husein, M.Q.; Bailey, M.T. and Ababneh, M.M. (1998a): Effect of eCG on the pregnancy rate of ewes transcervically inseminated with frozen-thawed semen outside the breeding season. Theriogenology, 49: 997-1005.

Husein, M.Q.; Romano, J.E. and Bailey, M.T. (1998b): Estrous synchronisation and pregnancy rate of transcervically inseminated ewes during the breeding season. Sheep Goat Res. J., 14: 148-152.

Kaabi, M. (2002): Analisis de factores morfoestructurales, instrumentales y metodologicos de la inseminacion transcervical en la oveja. Tesis Doctoral, Facultad de Veterinaria, Universidad de Leon, Spain.

Kaabi, M.; Alvarez, M.; Anel, E.; Chamorro, C.A.; Boixo, J.C.; de Paz, P. and Anel, L. (2006): Influence of breed and age on morphometry and depth of inseminating catheter penetration in the ewe cervix: a postmortem study. Theriogenology, 66: 1876-1883.

Kershaw, C.M.; Khalid, M.; McGowan, M.R.; Ingram, K.; Leethongdee, S.; Wax, G. and Scaramuzzi, R.J. (2005): The anatomy of the sheep cervix and its influence on the transcervical passage of an inseminating pipette into the uterine lumen. Theriogenology, 64: 1225-1235.

Langford, G.A.; Marcus, G.J.; Hackett, A.J.; Ainsworth, L.; Wolynetz, M.S. and Peters, H.F. (1979): A comparison of fresh and frozen semen in the insemination of confined sheep. Can. J. Anim. Sci., 59: 685- 691.

Lawrence, R. (1985): Preliminary results of nonsurgical intrauterine insemination of sheep with thawed semen. J.S. Afr. Vet. Assoc., 56: 61-63.

Leethongdee, S. (2010): Development of transcervical artificial insemination in sheep with special reference to anatomy of cervix. Suranaree J. Sci. Technol., 17: 57-69.

Lightfoot, R.J. and Salamon, S. (1970): Fertility of ram spermatozoa frozen by the pellet method. I. Transport and viability of spermatozoa within the genital tract of the ewe. J. Reprod. Fertil., 22: 385-398.

López-Gatius, F. (2000): Site of semen deposition in cattle: a review. Theriogenology, 53: 1407-1414.

Lymberopoulos, A.G.; Amiridis, G.S.; Kuhholzer, B.; Besenfelder, U.; Christodoulou, V.; Vainas, E. and Brem, E. (2001): Fertilization and embryo recovery rates in superovulated chios ewes after laparoscopic intrauterine insemination. Theriogenology, 55: 1855-1862.

Martin, I.C.A. and Watson, P.F. (1976): Artificial insemination of sheep: effects on fertility of number of spermatozoa inseminated and the storage of diluted semen for up to $18 \mathrm{~h}$ at $5 \circ \mathrm{C}$. Theriogenology, 5: 29-35.

Martinez, E.A.; Vazquez, J.M.; Roca, J.; Lucas, X.; Gil, M.A.; Parrilla, I.; Vazquez, J.L. and Day, $B . N$. (2002): Minimum number of spermatozoa required for normal fertility after deep intrauterine insemination in non-sedated sows. Reprod., 123: 163-170.

Maxwell, W.M.C. and Hewitt, L.J. (1986): A comparison of vaginal, cervical and intrauterine insemination of sheep. J. Agric. Sci., 106: 191-193.

Maxwell, W.M.C. and Salamon, S. (1993): Liquid storage of ram semen: a review. Reprod. Fertil. Dev., 5: 613-638.

McKelvey, W.; Robinson, J. and Aitken, R. (1985): The evaluation of a laparoscopic insemination technique in ewes. Theriogenology, 24: 519-535.

McKusick, B.C.; Thomas, D.L.; Gottfredson, R.G.; Zelinsky, R.D. and Berger, Y.M. (2000): A comparison of transcervical and laparoscopic intrauterine artificial insemination techniques on reproductive performance of ewes. Proc. 46th Annual Spooner Sheep Day, Dept. Animal Sci., Univ. of Wisconsin-Madison. pp. 32-39.

Milczewski, V.; Kozicki, L.E.; Luz, S.L.N. and Neves, J.P. (2000): Intrauterine and cervical artificial insemination in sheep using cooled semen. Arch. Vet. Sci., 5: 35-39.

Moore, R.W.; Miller, C.M. and Hall, D.R. (1988): Cervical versus laparoscopic AI of goat after PMSG injection at or 48 hours before CIDR removal. Proc. New Zealand Soc. Anim. Prod., 48: 69-70.

Morris, L.H.A. and Allen, W.R. (2002): An overview of low dose insemination in the mare. Reprod. Domest. Anim., 37: 206-210.

Naqvi, S.M.; Joshi, A.; Das, G.K. and Mittal, J.P. (2001): Development and application of ovine reproductive technologies: an Indian experience. Small Rumin. Res., 39: 199-208.

Nour, M.; Musa, M.S. and Makawi, S.A. (2010): Reproductive efficiency of desert sheep following surgical intrauterine artificial insemination in the Sudan Univ. of K. J. Vet. \& Anim. Prod., 1: 48-63.

Paulenz, L.; Soderquist, T.; CandAgric, A.; Nordstoga, B. and Berg, K.A. (2005): Effect of vaginal and cervical deposition of semen on the fertility of sheep inseminated with frozenthawed semen Vet. Rec., 156: 372-375. 
Rath, D. (2002): Low dose insemination in the sow-A review. Reprod. Domest. Anim., 37: 201-205.

Ritar, A.J. and Salamon, S. (1983): Fertility of fresh and frozen thawed semen of the Angora goat. Aust. J. Biol. Sci., 36: 49-59.

Ritar, A.J. (1993): Control of ovulation, storage of semen, and artificial insemination of fiberproducing goats in Australia: a review. Aust. J. Exper. Agric., 33:807-820.

Rodriguez, F.; Baldasarre, H.; Simonetti, J.; Aste, F. and Ruttle, J.L. (1988): Cervical versus intrauterine insemination of ewes using fresh or frozen semen diluted with aloe vera gel. Theriogenology, 30: 843-854.

Rojero, R.D.M.; Reyna-Santamaria, L.; MichelAceves, A.C.; Mastache-Lagunas, A.A.; Hernandez-Ignacio, $J$. and Rojas-Maya, $S$. (2009): Cervical or intrauterine artificial insemination in pelibuey ewes, with chilled semen. J. Anim. \& Vet. Advances, Faisalabad, 12: $2621-2625$

Romano, J.E. (2013): Assisted reproductive technologies in small ruminants. Clin. Theriogenology, 5: 293-310.

Salamon, S.; Evans, G. and Maxwell, W.M.C. (1985): Fertility of ram semen frozen-stored for 16 years. Ann. Conf. Aust. SOC. Reprod. Bio., 1: 62 abstr.

Salamon, S. and Maxwell, W.M.C. (1995): Frozenstorage of ram semen. II. Causes of low fertility after cervical insemination and methods of improvement. Anim. Reprod. Sci., 8: $1-36$.

Salamon, S. and Maxwell, W.M.C. (2000): Storage of ram semen. Anim. Reprod. Sci., 62:77-111.

Sayre, B.L. and Lewis, G.S. (1997): Fertility and ovum fertilization rate after laparoscopic or transcervical intrauterine artificial insemination of oxytocin-treated ewes. Theriogenology, 48: 267-275.
Sirjani, M.A.; Kohramb, H. and Shahira, M.H. (2012): Effects of eCG injection combined with FSH and GnRH treatment on the lambing rate in synchronized Afshari ewes. Small Rumin. Res., 106: 59-63.

Smith, J.F.; Parr, J. and Beaumont, S. (1995): Comparison of cervical, transcervical and laparoscopic insemination of ewes with chilled, stored and frozen ram semen. Proc. N.Z. Soc. Anim. Prod., 55: 248-250.

Snedecor, G.W. and Cochran, W.G. (1989): Statistical Methods. $8^{\text {th }}$ Ed. Iowa State Univ. Press, Ames, IA, USA.

Tervit, H.R.; Goold, P.G. and James, R.W. (1984): The insemination of sheep with fresh semen or frozen semen. Proc. N.Z. Soc. Anim. Prod., 44: 11-13.

Toni, D.; Plamen, T.; Vladimir, P.; Florina, P.; Ljupce, K. and Juraj, G. (2012): Laparoscopypromising tool for improvement of reproductive efficiency of small ruminants. Mac. Vet. Rev., 35: 5-11

Verberckmoes, S.; Van Soom, A.; De Pauw, I.; Dewulf, J.; Vervaet, $C$. and De Kruif, $A$. (2004): Assessment of a new utero-tubal junction insemination device in dairy cattle. Theriogenology, 61: 103-115.

Watson, P.F. and Behan, J.R. (2003): Intrauterine insemination of sows with reduced sperm numbers: Results of a commercially based field trial. Theriogenology, 57:,1683-1693.

Windsor, D.P.; Széll, A.Z. and Buschbeck, C. (1994): Transcervical artificial insemination of Australian Merino ewes with frozen-thawed semen. Theriogenology, 42: 147-157.

Wulster-Radcliffe, M.C.; Wang, S. and Lewis, G.S. (2004): Transcervical artificial insemination in sheep: Effects of a new transcervical artificial insemination instrument and traversing the cervix on pregnancy and lambing rates. Theriogenology, 62: 990-1002.

\section{دراسة مقارنة بين تلقيح النعاج البرقى بالمنظار داخل الرحم (بإستخدام جرعات مختلفة من السائل المنوى) وداخل عنق الرحم الرما}

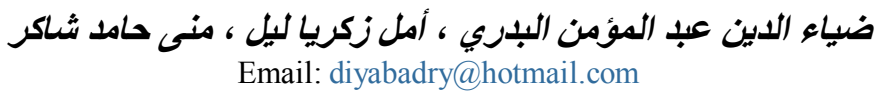

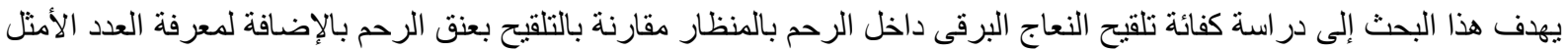

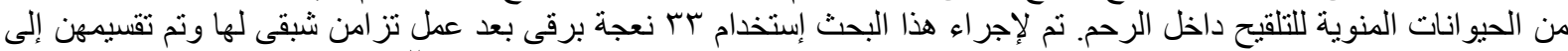

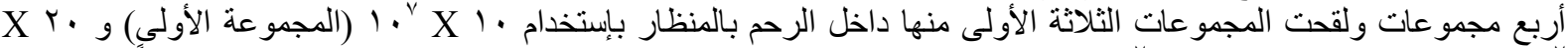

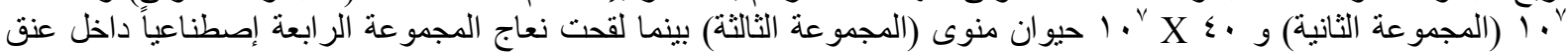

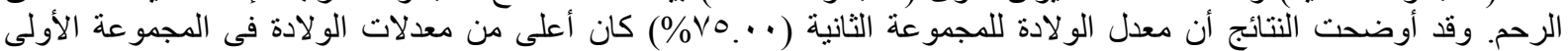

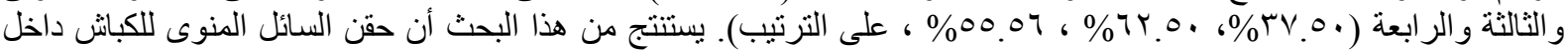

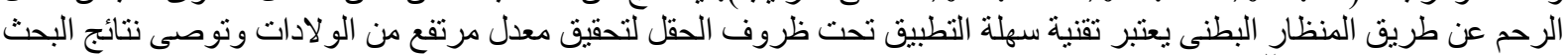

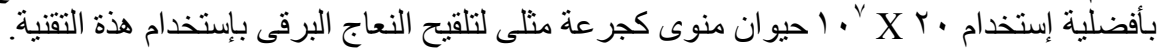

